\title{
Who Does Not Have a Bank Account in Hungary Today?*
}

\author{
Dániel Horn - Hubert János Kiss
}

Based on a representative sample, the study examines how regional variables and variables related to settlement type as well as demographic (gender, age), social (qualifications, income) and labour market characteristics (unemployment, public sector) and individual preferences (risk-taking and patience) are correlated with the fact that the respondent has a bank account or bank card or not. The authors find that having a bank account or bank card is not influenced by whether someone works in the public sector or not or by the individual's gender, while the effect of the preferences depends on the financial service. The impact of the other variables (age, education, income, unemployment) is in line with expectations and is significant separately as well as if they are taken into account simultaneously. The analysis shows that regional impacts and ones related to settlement type are also significant.

Journal of Economic Literature (JEL) codes: D14, G2, G4

Keywords: bank account, bank card, risk-taking, financial inclusion, socio-demographic characteristics, patience

\section{Introduction}

It is an accepted fact that financial services facilitate economic development at the macroeconomic level (Jayaratne - Strahan 1996; Levine 2005; Beck et al. 2007). For example, the spread of electronic payment methods may support economic growth, inter alia, through social cost savings (Bergman et al. 2007; Gresvik-Haare 2009). ${ }^{1}$ At the individual level, the use of financial services is often conducive to

\footnotetext{
* The papers in this issue contain the views of the authors which are not necessarily the same as the official views of the Magyar Nemzeti Bank.

Dániel Horn is a Senior Research Fellow at the Institute of Economics, Centre for Economic and Regional Studies, Hungarian Academy of Sciences and an Assistant Professor at the Department of Economics, Faculty of Social Sciences of the Eötvös Loránd University (ELTE).E-mail: horn.daniel@krtk.mta.hu

Hubert János Kiss is a Senior Researcher at the Institute of Economics, Centre for Economic and Regional Studies, Hungarian Academy of Sciences and an Assistant Professor at the Department of Economics, Faculty of Social Sciences of the Eötvös Loránd University (ELTE).E-mail: kiss.hubert.janos@krtk.mta.hu
}

The research serving as a basis for the study was supported by the Higher Education Institutional Excellence Programme of the Ministry of Human Capacities within the framework of the thematic programme 'Financial and Public Services' of Corvinus University of Budapest (20764-3/2018/FEKUTSRTAT).

The Hungarian manuscript was received on 15 June 2019.

DOI: http://doi.org/10.33893/FER.18.4.3554

${ }^{1}$ According to the calculations of Turján et al. (2011), a more modern payment system, for example one that uses less cash would entail social cost savings amounting to 0.4 per cent of GDP in Hungary. 
increasing savings (Dupas - Robinson 2013; Brune et al. 2016), helps the start-up of enterprises (Pitt - Khandker 1998; Augsburg et al. 2015; Banerjee et al. 2015a; Tarozzi et al. 2015) as well as with the management of risks and emergencies (poor harvest, job loss, health problems) (Karlan et al. 2014; Cai 2016; Cole et al. 2017). ${ }^{2}$ Those who do not have a bank account or bank card may not enjoy these benefits.

Based on the above, beyond the individual or household levels, it is understandable why promoting the use of basic financial services, i.e. financial inclusion, is an important public policy objective. In 2017, in Baden-Baden the G20 countries (and thus the countries of the European Union as well) committed themselves to promoting financial inclusion globally, and the World Bank announced the Universal Financial Access 2020 initiative. There are individual initiatives as well in a number of countries. In Hungary, for example, financial inclusion was also given a key role as one of the seven main objectives in the government's Strategy for Financial Education. $^{3}$

Concerning financial inclusion, the Global Findex database of the World Bank is an excellent starting point as in this topic it contains an immense amount of data for most of the countries. This database was created with the help of questionnaire surveys, during which 1,000 people were asked about financial matters in most of the countries (more people in larger countries). At the global level, financial inclusion has been assessed three times to date, with the last survey occurring in 2017. The report prepared on the basis of the database (Demirguc-Kunt et al. 2018) reveals that the reasons for financial exclusion may be the following: a) the financial institution is too far away; b) the service is too expensive; c) lack of necessary documents; d) lack of trust in credit institutions; e) bank services are not used for religious reasons; f) no money to put in the bank; g) someone else in the family has an account; and $h$ ) no need for financial services.

This survey reveals that in 2017, 75 per cent of the population in Hungary had a bank account. There is a difference of 6 percentage points between men and women, and a difference of 12 percentage points between the richest 60 per cent and the poorest 40 per cent in terms of having bank accounts. The data also show that the probability of having a bank account grows with age, education and active presence in the labour market. ${ }^{4}$ In developed countries, the ratio of bank account ownership (euro area: 95 per cent, USA: 93 per cent) is higher than in Hungary.

\footnotetext{
${ }^{2}$ Demirguc-Kunt et al. (2017) and Karlan - Morduch (2010) provide great insight into the literature. It is important to note that access to financial services does not always clearly improve the situation of households or firms. Many studies have not found any positive impact (e.g. Kaboski-Townsend 2012, Dupas et al. 2018), or consider the impacts to be only moderate (Banerjee et al. 2015b).

3 The OECD National Strategies for Financial Education: OECD/INFE Policy Handbook contains further useful information about national strategies regarding financial culture (OECD 2015).

${ }^{4}$ On the website of the World Bank, individual-level data are also available, which provide information not only about the use of financial services but also about gender, age, education, income quintile and the labour market situation.
} 
Although the figure for Hungary is better than the global average (63 per cent), the situation is more favourable in many of the neighbouring countries compared to Hungary (Czech Republic: 81 per cent, Croatia: 86 per cent, Poland: 87 per cent, Slovakia: 84 per cent and Slovenia: 98 per cent). As financial inclusion is higher in these countries, whose history and level of development are similar to those of Hungary, it indicates that there may be room for progress.

In addition to the World Bank survey, at various points this study shows common features with the work of Ilyés - Varga (2015), who also examined payment habits in Hungary with the help of a representative survey and also touched upon the question of what socio-demographic characteristics are the most typical of households which do not have bank accounts or bank cards. According to their data, 76 per cent of people have bank accounts and 72 per cent have bank cards. They find high bank account and bank card coverage (of around 90 per cent) up to the age of 50, while financial inclusion is lower in the older age-groups. In these older age-groups, bank card ownership is lower than bank account possession. Education also has a significant effect: average coverage is higher among those with a higher educational level. While less than half of those with 8 years or less of elementary education have a bank account or bank card, and the ratio of vocational school graduates who possess a bank account or bank card (72 per cent and 67 per cent, respectively) is also lower than the national average, in the case of those who have a secondary school leaving certificate these figures already exceed the national average ( 88 per cent and 86 per cent, respectively). The highest coverage is observed among degree holders (96 per cent and 95 per cent, respectively). The correlation between income and ownership of a bank account or bank card is positive, although the impact is smaller than expected, as even in the lowest income groups coverage falls only slightly short of the national average. In terms of settlement type, coverage is the lowest among those who live in villages. Higher values are observed in the case of town-dwellers, while the coverage values are the highest among those who live in county seats or Budapest. In terms of labour market status, coverage is highest among active employees, while the figures for pensioners and unemployed are below the national average. As there may be a correlation between these effects, the authors used logistic regression analysis to find which characteristic(s) have the greatest impact. They found that all of the aforementioned variables are important for understanding the ownership of bank accounts and bank cards, and their impact is significant even if the other variables are taken into account. Respondents who did not have a bank account or bank card were asked about the reasons. The most frequent answer (90 per cent) was that they did not consider these financial services necessary, while others mentioned the high costs ( 25 per cent and 19 per cent of the respondents in relation to bank accounts and bank cards, respectively). Few people indicated lack of confidence in credit institutions (10-11 per cent) or perceived security risks (3-4 per cent). 
This study is based on the data of the TÁRKI Omnibus survey conducted in early 2017. Compared to the World Bank database, the study by Ilyés - Varga (2015) is richer, and the database used in this study contains even more variables. We have information on the respondents' risk and time preferences and even about whether they work in the private sector or the public sector. As is presented, according to our expectations these variables may also affect bank account and bank card ownership. The main question of the study is who does not use basic financial services in Hungary at present, which we measure with the ownership of retail bank accounts and bank or credit cards.

The next section presents the data and hypotheses, while in the third section we discuss our findings with the help of descriptive statistics followed by regression analysis. Finally, we draw the conclusions.

\section{Data and hypotheses}

In 2017 Q1, the Omnibus survey of TÁRKI took a 1,000-person sample of individuals aged $18+$, which was representative in terms of gender, age, education and settlement type. The sample provides a thorough survey of the respondents' demographic (age, gender), economic and social (educational level, income, labour market status, residence) situations. Below is a brief presentation of the most important variables.

The Omnibus survey measures the educational level on a nine-grade scale, from less than 8 years of elementary to university. These nine categories are used in the descriptive part, but in the regression analysis we transformed this variable into one that measures the years spent at school. ${ }^{5}$

As far as income is concerned, the survey asks about the income of both the individual and the household. Respondents could give net income and estimated income at both levels. In the latter case, they had to choose their income level from the given ranges (HUF 20,000 or below, HUF 21,000-40,000, HUF 41,00070,000, HUF 71,000-100,000, HUF 101,000-150,000, HUF 151,000-200,000, HUF 201,000-300,000, HUF 301,000-500,000). Both at the individual and household levels far more people indicated net income than estimated income. We formed the two types of income for all respondents using imputation with the help of control variables concerning mainly consumer durables and real property. Fewer people (456) gave responses regarding household-level income than individual-level income (722). However, individual and household incomes strongly correlate; the correlation coefficient is 69 per cent and 66 per cent for net and estimated incomes,

\footnotetext{
${ }^{5}$ We assigned 6 years to the category of less than 8 years of elementary school, and the shortest period of time needed for graduation to the other categories.
} 
respectively, and the correlation is significant ( $p<0.0001$ in both cases). Individuallevel net income and its imputed values were used in the descriptive statistics and in the regression.

Two dimensions are examined in the case of the labour market status. Firstly, whether the respondent works when the question is asked, and secondly, we also have information whether the person works in the public sector. The use of this variable in the analysis was justified by the assumption that those working in the public and private sectors receive their salary by transfer to a bank account to different degrees. ${ }^{6}$ More exactly, our expectation was that most of those working in the public sector receive their salary to a bank account, contrary to the private sector, where this practice is less widespread. And the outcome may be that employment in the public sector in itself explains the higher degree of having a bank account, irrespective of other variables.

We examined two aspects of the dwelling place as well. Firstly, which region the respondent lives in, and secondly, the settlement type. The latter contains four categories: Budapest, county seat, town, or village.

In addition, we have data on the respondents' risk and time preferences, which were surveyed by TÁRKI at the authors' request. Risk preferences were assessed with the help of a hypothetical question. The respondent had to decide, if he received HUF 10,000 , what percentage of that he would spend on a gamble where there is a 50 per cent chance to win the double of the amount staked and equal probability to lose it. Sutter et al. (2013) also used this test, which basically corresponds to the investment game of Gneezy and Potters (1997), which is often used to measure risk attitudes (see, for example, Charness - Gneezy 2012, Crosetto - Filippin 2016). The amount staked on the gamble can be considered the natural measure of risk-taking, as the higher percentage the respondent would spend on gambling, the higher risk he is ready to take. Based on Falk et al. (2018), we assessed the time preference with the help of five interdependent choices between immediate and delayed financial rewards. For example, the respondent had to decide whether he would like to receive HUF 10,000 today or HUF 15,500 in a month. Depending on the answer, we changed the latter amount in order to be able to roughly assess by five questions what amount available in a month would be equivalent for the respondent to today's HUF 10,000 . The quotient of the two amounts (HUF 10,000/HUF in a month) gives the respondent's discount factor, i.e. how he evaluates the future compared to the present. In recent literature, this preference has started to be referred to as patience. The higher this quotient, the more patient the individual is. The examination of preferences is justified by the fact that on the basis of microeconomics, in addition to constraints and opportunities,

\footnotetext{
${ }^{6}$ Demirguc-Kunt et al. (2018) also call attention to the fact (see Section 3) that if those working in the public sector receive their salary to a bank account, it may significantly affect the differences in bank account ownership seen across countries.
} 
individuals' decisions are determined by their preferences. In line with this, the examination of the role of preferences has become increasingly important in recent years. As mentioned in the introduction, the use of financial instruments and financial inclusion may significantly facilitate the management of risks and emergencies, and thus we might expect that risk attitude may have a correlation with the use of basic financial services. Many recent studies examine the relationship between patience and accumulation decisions, and especially financial decisions within the latter. Sutter et al. (2013) observe, for example, that more impatient young people save less in Austria. Bradford et al. (2017) identify a positive correlation between patience and savings on a representative US sample. Falk et al. (2018) find that this correlation exists at the global level as well. ${ }^{7}$ On the basis of the findings presented we thought that patience may also be correlated with financial inclusion. More specifically, we expect that more patient individuals (who discount the future to a lesser extent) save more, and thus we expect that they are more willing to use financial services than their less patient compatriots. ${ }^{8}$ It is important to note that preferences may affect the other variables as well, for example, more patient individuals may have higher qualifications. ${ }^{9}$ In the regression analysis, however, we can take into account these indirect effects by including the above variables, and thus we can examine whether preferences have an impact on the use of basic financial services beyond these indirect effects as well.

In the survey, there were two questions concerning basic financial instruments: 'Do you have a retail bank account?' and 'Do you have a bank card or credit card?'. ${ }^{10}$ In the Hungarian questions the pronoun 'you' is used explicitly both in the singular and plural sense, so that the unit of observation is not clear; the individual level and the household level are not clearly separated. It is not even an objective to precisely separate them, as in terms of financial inclusion it is not the point whether the individual has a bank account or bank card or not, but the point is that there should be an individual like that in his/her environment in a narrow sense. ${ }^{11}$

As a first step, we examine whether we can confirm the findings of the World Bank analysis or the study by Ilyés - Varga (2015) using our data, i.e. whether we can find any difference in the use of basic financial instruments on the basis of gender, age, education, income, labour market status or settlement type. We expect that in terms of these variables our findings will also be similar to those of the World Bank survey and the study by Ilyés - Varga (2015). Neither the World Bank, nor Ilyés - Varga (2015) examine the effect of whether someone works in the public

\footnotetext{
${ }^{7}$ It should be mentioned that certain studies (e.g. Chabris et al. 2008) do not find any correlation between patience and financial decisions.

8 Using these same data, Horn - Kiss (2019) find that patience has a significant impact on savings decisions, even if a number of factors (such as demographic characteristics, educational level, income) are taken into consideration.

${ }^{9}$ See, for example, Golsteyn et al. (2014) or Horn - Kiss (2019).

${ }^{10}$ For the sake of simplicity, the term bank account is used instead of current account as well as bank card in lieu of bank card or credit card in this study.

${ }^{11}$ Ilyés - Varga (2015, Part 4.1) do the same.
} 
sector, and none of the studies deals with the effect of preferences. Therefore, our study contributes to the existing literature, and shows whether these variables are important in the understanding of who has a bank account or bank card.

In addition to the above, we also examine if regional disparities affect whether the respondent uses basic financial services. It may happen, for example, that in a richer region even poorer people have a bank account, while in poorer regions they do not. Based on the above considerations we expect that we will find regional disparities, and in richer regions the use of basic financial services will be higher, ceteris paribus.

\section{Results}

\subsection{Descriptive statistics}

According to the survey, 82.9 per cent of the respondents have a bank account and 83.2 per cent have bank cards. 83.1 per cent of women and 82.7 per cent of men have a bank account, while the figures for bank cards are 83.6 per cent and 82.7 per cent, respectively. ${ }^{12}$

Table 1 shows the characteristics of individuals who do not have a bank account or bank card (column 'No') and those who have one (column 'Yes'), and whether the difference seen in these characteristics is statistically significant or not.

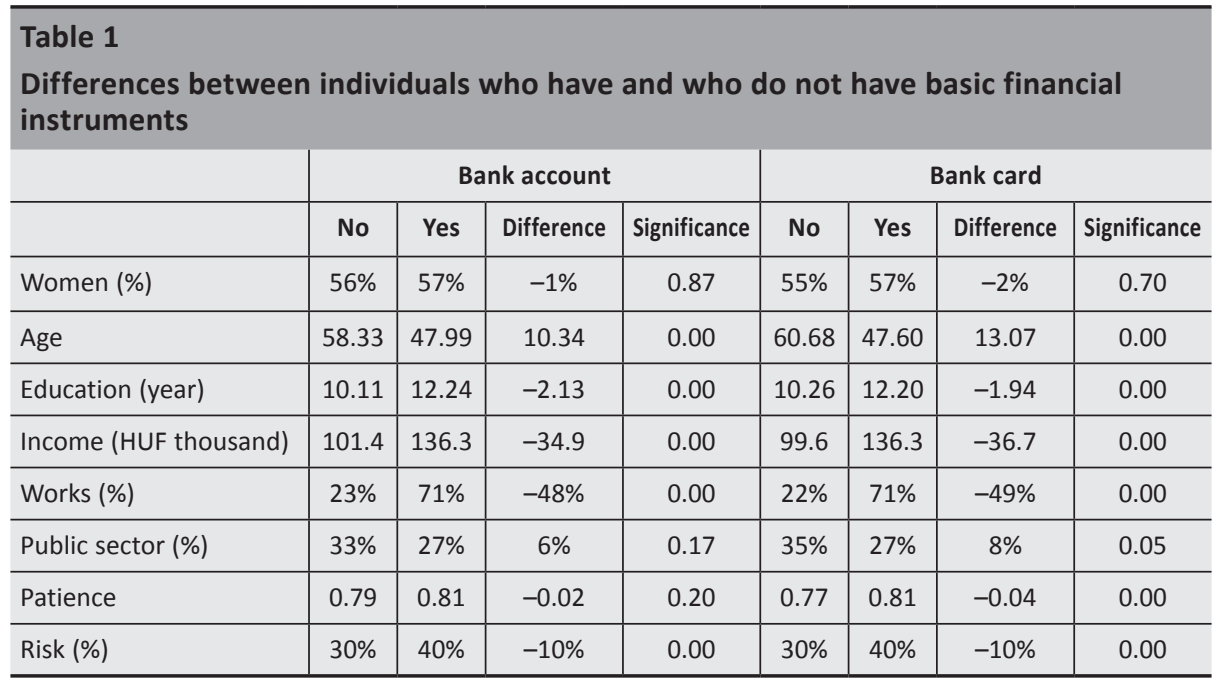

\footnotetext{
${ }^{12}$ These figures are higher than the ones mentioned by llyés - Varga (2015) (75.7 per cent have a bank account, and 71.7 per cent hold a bank card), but those data are from 2014. It is to be noted that 22 and 24 of the respondents did not want to or could not answer the questions concerning bank account and bank card ownership, respectively.
} 
Clearly, as opposed to the World Bank survey, we do not see any gender difference. The ratio of women among those who do not use basic financial services is slightly higher compared to the ones who use them, although the difference is not significant.

Looking at the age, we can see that the individuals who have a bank account / bank card are typically younger than those who do not have a bank account / bank card, and the difference is significant. As regards age, two effects play a role. Firstly, as respondents grow older, their income grows, and there is an increased probability that they will use the basic financial services. Accordingly, as opposed to what is shown in Table 1, one would expect that the individuals that have a bank account / bank card are typically older. Secondly, it may be the case that many of the elder, mainly country people grew up without using these services, and did not use them later either. It seems that the second effect dominates, and the older age-group uses the basic financial services to a lesser degree than young people. This is corroborated by Figure 1, which shows that among those who are older than the generation that is around the age of 55 the use of bank account and bank card declines strongly with age. Looking at the use of bank accounts it is also seen that in the case of young people the probability of use grows with age. These findings are very similar to those of Ilyés - Varga (2015). We can also see, as they do, that bank account coverage is typically higher than bank card coverage in the case of the older age-groups.

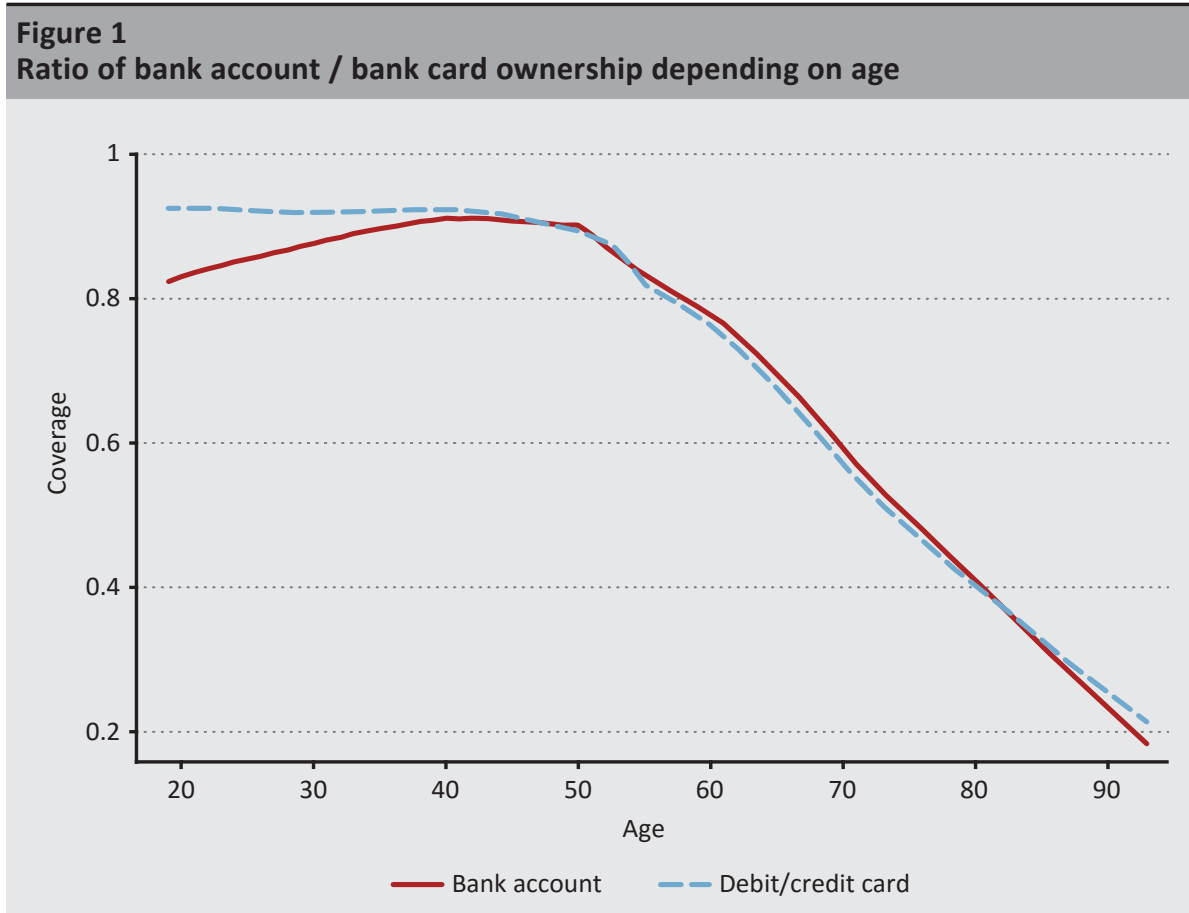


Figure 2 depicts how the ratio of bank account and bank card ownership changes with educational level. Similarly to the study by Ilyés - Varga (2015), we see the expected correlations: the ratio of bank account and bank card ownership increases with the educational level, although the growth rate is lower and lower. While among the people who did not finish more than 8 years of elementary school (this group of respondents is constituted by the first two lines in Figure 2) the ratio of bank account ownership is 56.29 per cent, and that of bank card ownership is 57.49 per cent, in the case of vocational school graduates these figures rise to 82.45 per cent for both financial instruments. For those with a secondary school leaving certificate (in Figure 2 this group of respondents corresponds to the combination of lines four and five), bank account ownership is 90.16 per cent, while bank card ownership is at 92.36 per cent. As these are already high numbers, higher education (the last two lines in Figure 2) can contribute only to a modest improvement in the figures ( 97.73 per cent have a bank account, and 93.89 per cent have a bank card)..$^{13}$

\section{Figure 2}

Ratio of bank account / bank card ownership depending on education

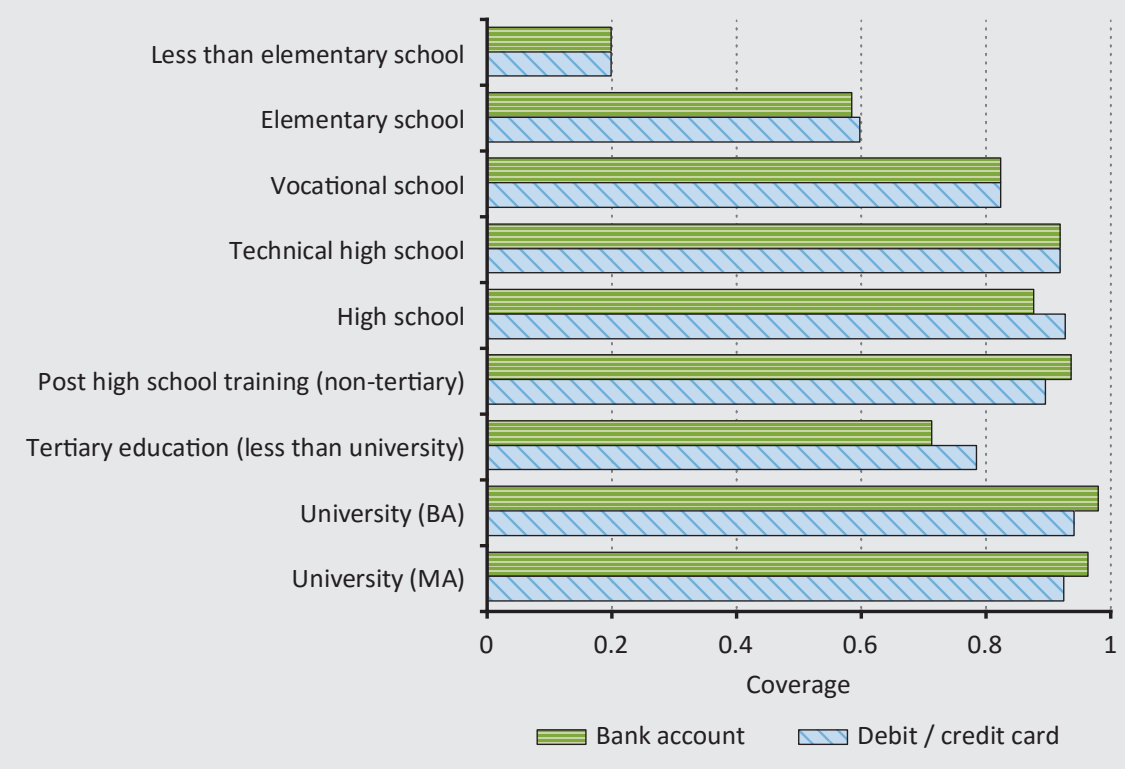

${ }^{13}$ The category 'Tertiary education (less than university)' contains 15 observations. The low number of observations may explain the slight deviation of the results from the trend. 
Education significantly determines income as well. Therefore, it is no surprise that according to Table 1 the income of individuals with a bank account / bank card is significantly higher, i.e. by HUF 35,000. Concerning bank accounts, Figure 3 complements this conclusion with the fact that bank account ownership grows together with income up to around HUF 200,000, but above that income no change is observed, or in the case of high incomes even a slight decline is seen in the data. In the case of bank cards, their ownership ratio rises continuously with income, although the growth rate declines steadily, as complete coverage is approached.

\section{Figure 3}

Ratio of bank account / bank card ownership depending on income

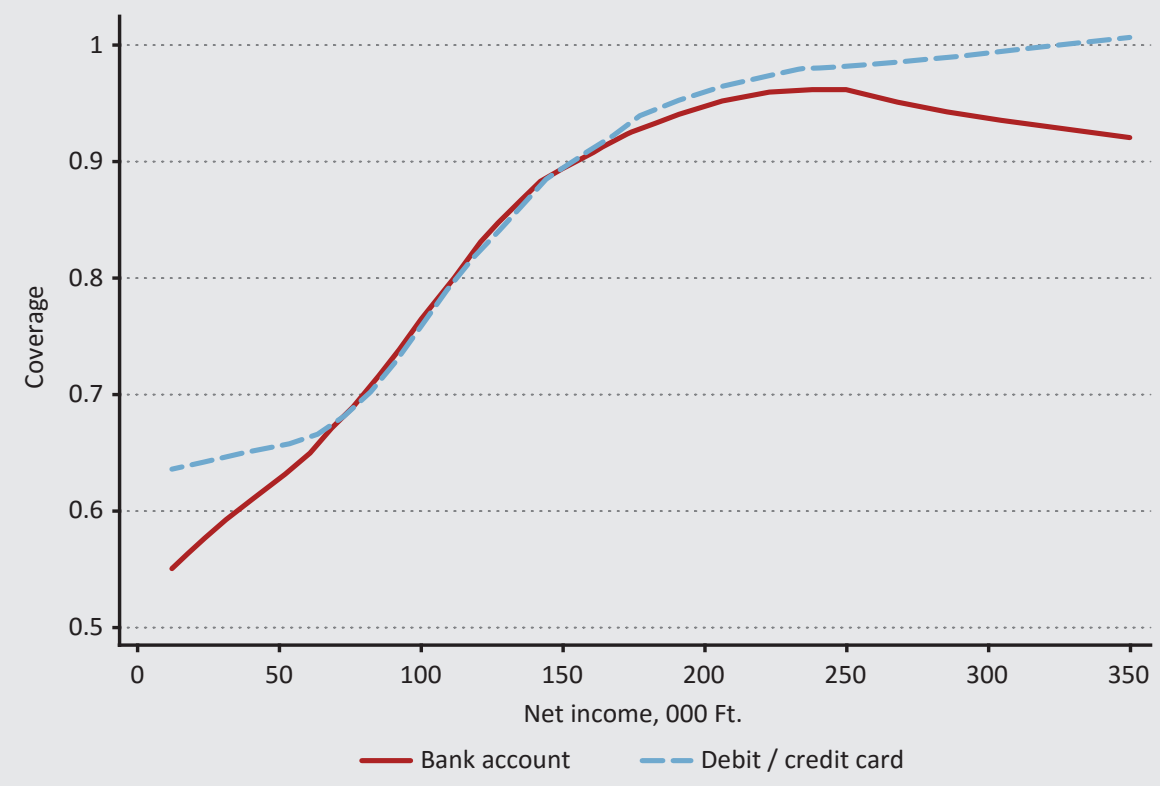

Similarly to the World Bank analysis and the study by Ilyés - Varga (2015), the data in Table 1 show that the use of basic financial services is correlated with the labour market situation: among bank account and bank card owners the ratio of those who have a job is significantly higher. ${ }^{14}$ At first sight it may seem strange and contradictory to our hypothesis formulated on the basis of the World Bank analysis that among those who do not use the basic financial services the ratio of

\footnotetext{
${ }^{14}$ One underlying reason may also be that many of the poorer families are indebted, and for them it is not worth to have a registered job, as one third of their income would immediately be deducted for repayment. See, for example: https://www.portfolio.hu/finanszirozas/hitel/bedolt-hitelek-van-remeny-a-szegenyeknekitt-a-megoldas.305659.html
} 
those who work in the public sector is higher, and this difference is significant in the case of bank cards. Apparently, public sector employees are very heterogeneous in the sense that those who do intellectual work as state employees (who, without exception, probably receive their salaries to a bank account) as well as physical workers and public workers employed by local governments (for whom cash payment may be the usual method) are treated alike.

Based on Table 1, in terms of preferences, patience is not correlated with bank account ownership, but individuals who have a bank card seem to be significantly more patient than those who do not hold a bank card, although the numerical difference is not substantial. As for risk-taking, regarding both bank accounts and bank cards, those who use these basic financial services are significantly more willing to take risks. These findings are reflected by Figure 4 as well.

Figure 5 illustrates the regional disparities. It is clear that there are such regional disparities. Recourse to basic financial services is the lowest in Southern Transdanubia (the ratio of bank account and bank card ownership is 77.08 per cent and 73.68 per cent, respectively), while Western Transdanubia and the Southern Great Plain are the leaders with bank account ownership of more than 90 per cent and bank card ownership reaching 87 per cent. The differences are significant at the national level, but only at a 5 per cent significance level in the case of bank cards.

Figure 6 shows that settlement type is also correlated with the use of basic financial services. Proceeding from county seat to village, the ratio of both bank account (from 88.13 per cent to 79.59 per cent) and bank card ownership (from 90.63 per cent to 78.91 per cent) declines. The explanation may be similar to the one described in the World Bank report and the study by Ilyés - Varga (2015), i.e. these services are not available in smaller settlements. But it is also possible that in these settlements the educational level and the income of the population is lower, and based on the above we have seen that this may also be behind the lower use of financial services. Interestingly, and contrary to the study by Ilyés - Varga (2015), according to our data the ratio of bank account ownership is the lowest in Budapest, and Budapest does not reach the level of towns in bank card ownership either. As in the case of regions, settlement types also significantly explain the dispersion of bank account and bank card ownership, but only at a significance level of 5 per cent in the case of bank cards. 


\section{Figure 4}

Ratio of bank account / bank card ownership depending on patience and risk-taking
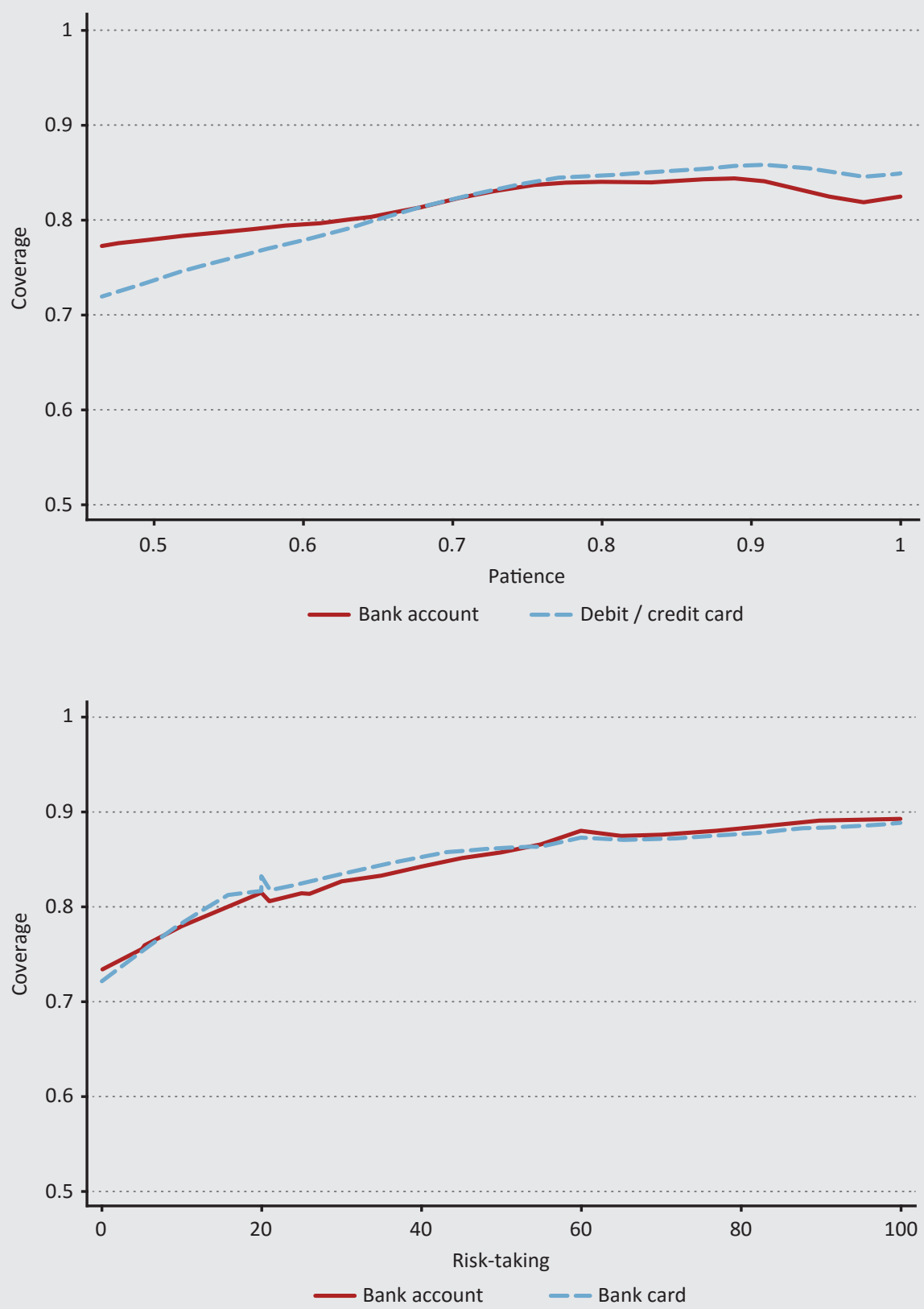


\section{Figure 5}

Regional disparities in using basic financial services

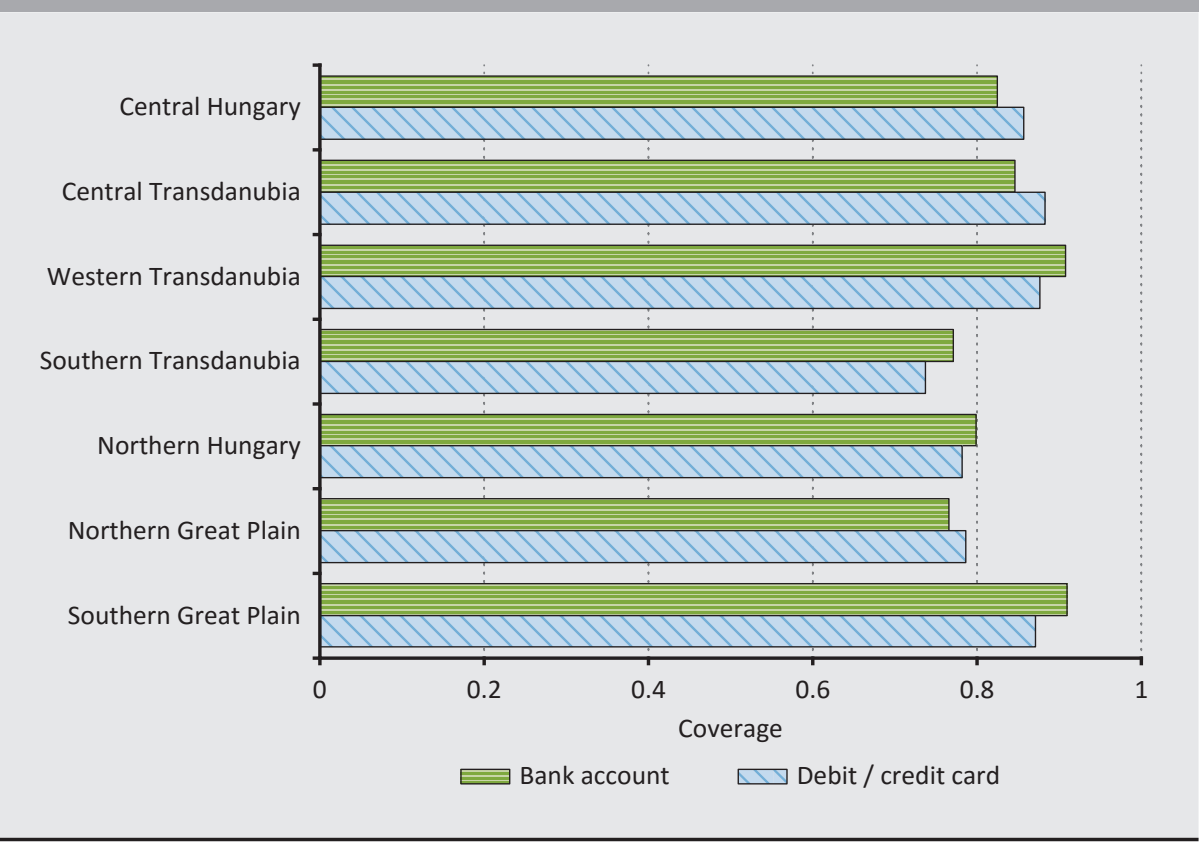

Figure 6

Ratio of bank account / bank card ownership in various settlement types

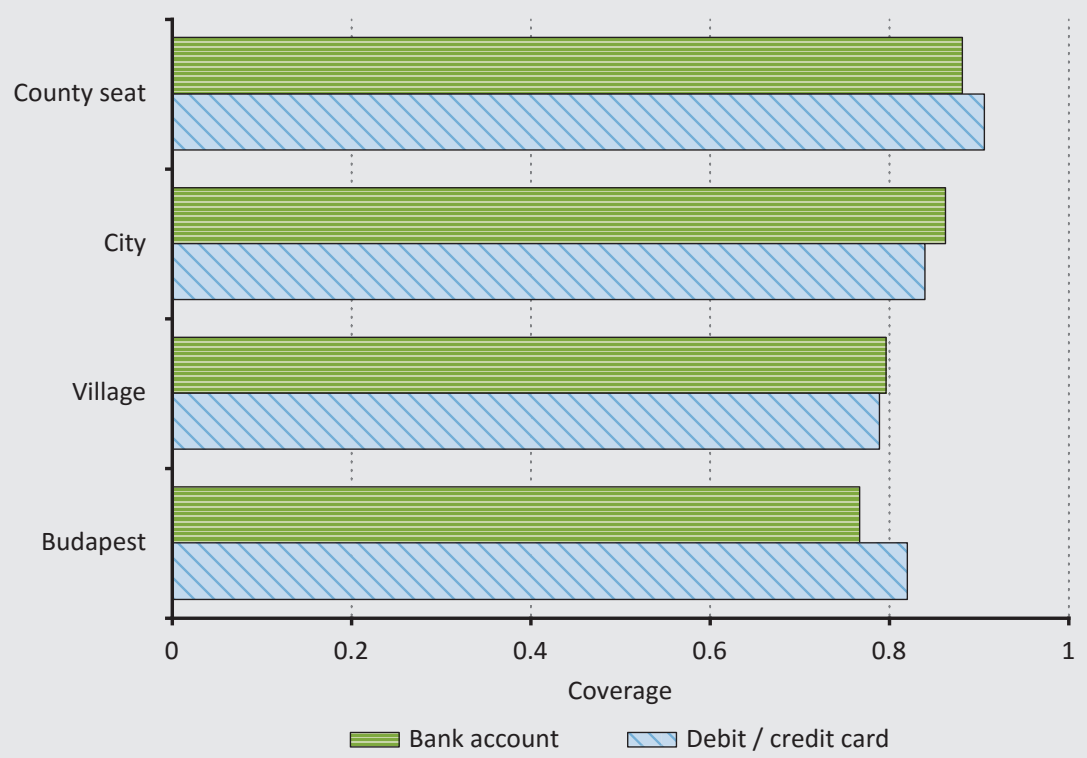




\subsection{Regression analysis}

In this section, with the help of regressions we attempt to better understand who does not have a bank account / bank card in Hungary. The advantage of this analysis is that we can take into account the various impacts simultaneously, and thus it is possible to verify whether a variable proves to be significant in the descriptive statistics only because it correlates with another variable.

Using the ordinary least squares (OLS) method we would like to understand what influences whether a respondent has a bank account or bank card or not. The dependent variable is a binary variable, whose value is 1 if the respondent has the given financial product; otherwise it is $0 .{ }^{15}$

The explanatory variables in Table 2 are identical to the ones seen before. Of the demographic variables, the value of the woman dummy is 1 if the respondent is a woman; otherwise it is 0 . In the case of the age, the quadratic term was also taken into account, as the inverted $U$ in Figure 1 indicates the presence of non-linear effects. We examine the effects of education (educational level is measured here with the years spent at school) and income, as well as whether the fact that the respondent works affects the ownership of the financial product under review. We also examined whether it has an impact if the respondent works in the public sector. We also took into account the effects of patience and risk preferences. Finally, we also examined the effects of regional and settlement type dummies.

We transformed the coefficient of the explanatory variables in order to be able to interpret them on a percentage basis. This was done because if the value of an explanatory variable increased by one unit, the coefficient shows how many percentage points greater the chance would be that the respondent has the given financial product, while the values of the other variables remain unchanged.

\footnotetext{
${ }^{15}$ In the case of a binary independent variable the application of other, non-linear specification is also possible. In the event that logit or probit regressions are used in lieu of linear ones, with the specification below, we come to qualitative results that are very similar to the ones described.
} 


\begin{tabular}{|c|c|c|}
\hline \multicolumn{3}{|l|}{$\begin{array}{l}\text { Table } 2 \\
\text { Regression analysis }\end{array}$} \\
\hline \multirow[b]{3}{*}{ Variables } & (1) & (2) \\
\hline & \multicolumn{2}{|c|}{ Dependent variable: Does the respondent have a } \\
\hline & bank account? & bank card? \\
\hline Woman, dummy & $\begin{array}{c}1.706 \\
(2.571)\end{array}$ & $\begin{array}{l}2.106 \\
(2.567)\end{array}$ \\
\hline Age & $\begin{array}{c}1.699 * * * \\
(0.515)\end{array}$ & $\begin{array}{c}1.237^{* * *} \\
(0.466)\end{array}$ \\
\hline Age square & $\begin{array}{c}-0.0199 * * * \\
(0.00550)\end{array}$ & $\begin{array}{c}-0.0173^{* * *} \\
(0.00510)\end{array}$ \\
\hline Education (year) & $\begin{array}{c}3.370 * * * \\
(0.611)\end{array}$ & $\begin{array}{c}1.995 * * * \\
(0.686)\end{array}$ \\
\hline Income (HUF thousand) & $\begin{array}{l}0.0522^{*} \\
(0.0275)\end{array}$ & $\begin{array}{c}0.0877^{* * *} \\
(0.0273)\end{array}$ \\
\hline Works, dummy & $\begin{array}{c}14.52^{* * *} \\
(3.861)\end{array}$ & $\begin{array}{c}11.69 * * * \\
(3.697)\end{array}$ \\
\hline Public sector, dummy & $\begin{array}{l}-2.112 \\
(2.798)\end{array}$ & $\begin{array}{l}-1.668 \\
(2.931)\end{array}$ \\
\hline Patience & $\begin{array}{c}4.437 \\
(8.621)\end{array}$ & $\begin{array}{l}19.89 * * \\
(9.924)\end{array}$ \\
\hline Risk-taking & $\begin{array}{c}0.0176 \\
(0.0366)\end{array}$ & $\begin{array}{l}-0.0304 \\
(0.0393)\end{array}$ \\
\hline Central Transdanubia, dummy & $\begin{array}{l}-2.952 \\
(4.596)\end{array}$ & $\begin{array}{l}-4.303 \\
(4.581)\end{array}$ \\
\hline Western Transdanubia, dummy & $\begin{array}{c}0.118 \\
(5.040)\end{array}$ & $\begin{array}{l}-7.283 \\
(5.419)\end{array}$ \\
\hline Southern Transdanubia, dummy & $\begin{array}{r}-10.43^{*} \\
(5.568)\end{array}$ & $\begin{array}{c}-15.35^{* *} \\
(6.206)\end{array}$ \\
\hline Northern Hungary, dummy & $\begin{array}{l}-5.685 \\
(4.788)\end{array}$ & $\begin{array}{c}-9.217^{*} \\
(4.909)\end{array}$ \\
\hline Northern Great Plain, dummy & $\begin{array}{c}-9.557^{*} \\
(4.894)\end{array}$ & $\begin{array}{c}-11.82^{* *} \\
(5.230)\end{array}$ \\
\hline Southern Great Plain, dummy & $\begin{array}{l}-0.250 \\
(4.634)\end{array}$ & $\begin{array}{l}-5.431 \\
(4.890)\end{array}$ \\
\hline County seat, dummy & $\begin{array}{c}19.33 * * * \\
(5.850)\end{array}$ & $\begin{array}{c}17.46 * * * \\
(5.842)\end{array}$ \\
\hline Town, dummy & $\begin{array}{c}19.12 * * * \\
(4.954)\end{array}$ & $\begin{array}{c}13.73 * * * \\
(4.788)\end{array}$ \\
\hline Village, dummy & $\begin{array}{c}16.85^{* * *} \\
(5.314)\end{array}$ & $\begin{array}{c}11.60^{* *} \\
(5.119)\end{array}$ \\
\hline Constant & $\begin{array}{l}-19.89 \\
(15.44)\end{array}$ & $\begin{array}{c}5.107 \\
(13.98)\end{array}$ \\
\hline Number of observations & 862 & 862 \\
\hline R-square & 0.258 & 0.249 \\
\hline
\end{tabular}


It is visible in Table 2 that similarly to what was seen in the descriptive statistics, gender and working in the public sector do not affect the use of the financial products under review. Looking at the preferences, in terms of patience we can see the same thing as in the case of the descriptive statistics, i.e. it does not have an impact in the case of bank accounts, but more patient people are more likely to possess a bank card. ${ }^{16}$ The effect of risk-taking disappears in the regression analysis, i.e. the other variables absorb the effect of risk-taking. Interestingly, but at the same time similarly to the study by llyés - Varga (2015), although there may be interrelationships between the other individual variables (e.g. higher level of education usually entails higher income), their effect still remains significant, i.e. they are important determinants of bank account and bank card ownership by themselves, not only as a result of their correlation with other variables. More specifically, it is seen from the regression that the probability of ownership of the financial products under review rises with age, but the growth rate declines steadily. Moreover, the use of basic financial products by older people also declines, as shown by the negative sign of the square of age. Plus one year spent at school increases the probability of bank account and bank card ownership by 3.4 and 2 percentage points, respectively, ceteris paribus. This is a very significant effect, like in the study by Ilyés - Varga (2015). Income also has a significant positive effect; income HUF 100,000 higher increases the use of bank account and bank card by 5.2 and 8.8 percentage points, respectively, i.e. the effect on bank card ownership is stronger here. It has a very strong effect if someone works: it increases the use of the financial products under review by more than 10 percentage points, if all the other variables are unchanged. Regional variables show that compared to Central Hungary, basic financial services are used to a lesser extent in Southern Transdanubia and in the Northern Great Plain. Settlement type dummies, in turn, show that the financial products under review are used to a greater degree in other settlement types compared to Budapest.

The number of observations in the regression is less than one thousand because if any of the above variables is missing in the case of a given respondent, the latter was not taken into account in the regression analysis. The above regressions are able to explain one quarter of the variance in the ownership of the financial products under review.

\section{Conclusions}

The objective of this study was to characterise those individuals who do not use basic financial services. They may be the main target groups of the programmes that facilitate financial inclusion. We cannot see any gender differences, i.e. based

\footnotetext{
${ }^{16}$ It is not clear why the effect of patience is different in the case of these two basic financial instruments. Further research is necessary to find out whether it is only the peculiarity of our sample or there is another underlying explanation.
} 
on our sample, women do not use bank accounts or bank cards to a lesser extent than men. Whether someone works in the public or private sector also does not help to understand who does not use the basic financial products. Bank account and bank card ownership rises with age in the beginning, but then declines. Education, income and employment all significantly increase the use of basic financial services. These effects by themselves are not surprising; common sense would also suggest these findings. However, the regression analysis also revealed that the aforementioned effects exist not only separately, but also in the presence of the other effects. Looking at the preferences, the effects are more complex. Examining them separately, risk-taking seems to be important; people who are more risk-tolerant are more inclined to use the basic financial products, but this effect disappears in the regression analysis, i.e. the other explanatory variables absorb the effect of risk-taking. Patience seems to be significant in connection with bank card ownership; more patient people are more inclined to hold a bank card, but it does not have an effect on bank account ownership. One of the lessons from the study is that the new variables (working in the public sector, patience and risk-taking) included in addition to the ones used before do not provide any significant help in understanding who does not use these basic financial services.

We can see that in addition to individual characteristics, regional effects are also significant; compared to Central Hungary, there are three regions where bank card ownership is significantly lower, even after taking into account all the other variables. Differences according to settlement type are also significant; basic financial services are used to a lesser extent in smaller settlements, in many cases probably because they are locally not available.

In connection with the findings, the constraints of the analysis are also worth mentioning. The data are based on the respondents' answers, which may not completely reflect reality. The underlying reason may be that the respondents do not know the exact answer, but instead of admitting it, they say something to the question, or their answers are simply wrong. This data quality problem is unavoidable in the case of surveys like this; it is not possible to systematically check whether the answers are true. Our findings indicate such possible problems originating from measurement errors in two cases. Firstly, taking into account the low number of prepaid bank cards it is strange that in many cases we see that bank card ownership (sometimes significantly) exceeds bank account ownership. Secondly, the fact that bank card coverage is the lowest in Budapest also indicates potential problems related to data quality. ${ }^{17}$ Considering all these constraints, we hope that our study will help to provide a more precise picture of the factors that hinder financial inclusion, making the latter easier to achieve.

\footnotetext{
${ }^{17}$ We thank one of our anonymous reviewers for calling our attention to this problem.
} 


\section{References}

Augsburg, B. - De Haas, R. - Harmgart, H. - Meghir, C. (2015): The impacts of microcredit: Evidence from Bosnia and Herzegovina. American Economic Journal: Applied Economics, 7(1): 183-203. https://doi.org/10.1257/app.20130272

Banerjee, A. - Duflo, E. - Glennerster, R. - Kinnan, C. (2015a): The miracle of microfinance? Evidence from a randomized evaluation. American Economic Journal: Applied Economics, 7(1): 22-53. https://doi.org/10.1257/app.20130533

Banerjee, A. - Karlan, D. - Zinman, J. (2015b): Six randomized evaluations of microcredit: Introduction and further steps. American Economic Journal: Applied Economics, 7(1): 1-21. https://doi.org/10.1257/app.20140287

Beck, T. - Demirgüç-Kunt, A. - Levine, R. (2007): Finance, inequality and the poor. Journal of Economic Growth, 12(1): 27-49. https://doi.org/10.1007/s10887-007-9010-6

Bergman, M. - Guiborg, G. - Segendorf, B. (2007): The Costs of Paying - Private and Social Costs of Cash and Card Payments. Riksbank Research Paper Series 212. https://doi. org/10.2139/ssrn.1022266

Bradford, D. - Courtemanche, C. - Heutel, G. - McAlvanah, P. - Ruhm, C. (2017): Time preferences and consumer behavior. Journal of Risk and Uncertainty, 55(2-3): 119-145. https://doi.org/10.1007/s11166-018-9272-8

Brune, L. - Giné, X. - Goldberg, J. - Yang, D. (2016): Facilitating savings for agriculture: Field experimental evidence from Malawi. Economic Development and Cultural Change, 64(2): 187-220. https://doi.org/10.1086/684014

Cai, J. (2016): The impact of insurance provision on household production and financial decisions. American Economic Journal: Economic Policy, 8(2): 44-88. https://doi. org/10.1257/pol.20130371

Chabris, C.F. - Laibson, D. - Morris, C.L. - Schuldt, J.P. - Taubinsky, D. (2008): Individual laboratory-measured discount rates predict field behavior. Journal of Risk and Uncertainty, 37(2-3): 237-269. https://doi.org/10.1007/s11166-008-9053-x

Charness, G. - Gneezy, U. (2012): Strong evidence for gender differences in risk taking. Journal of Economic Behavior \& Organization, 83(1): 50-58. https://doi.org/10.1016/j. jebo.2011.06.007

Cole, S. - Giné, X. - Vickery, J. (2017): How does risk management influence production decisions? Evidence from a field experiment. The Review of Financial Studies, 30(6): 19351970. https://doi.org/10.1093/rfs/hhw080 
Crosetto, P. - Filippin, A. (2016): A theoretical and experimental appraisal of four risk elicitation methods. Experimental Economics, 19(3): 613-641. https://doi.org/10.1007/ s10683-015-9457-9

Demirguc-Kunt, A. - Klapper, L. - Singer, D. (2017): Financial inclusion and inclusive growth: A review of recent empirical evidence. The World Bank. https://doi.org/10.1596/18139450-8040

Demirguc-Kunt, A. - Klapper, L. - Singer, D. - Ansar, S. - Hess, J. (2018): The Global Findex Database 2017: Measuring financial inclusion and the fintech revolution. The World Bank. https://doi.org/10.1596/978-1-4648-1259-0

Dupas, P. - Robinson, J. (2013): Savings constraints and microenterprise development: Evidence from a field experiment in Kenya. American Economic Journal: Applied Economics, 5(1): 163-192. https://doi.org/10.1257/app.5.1.163

Dupas, P. - Karlan, D. - Robinson, J. - Ubfal, D. (2018): Banking the Unbanked? Evidence from three countries. American Economic Journal: Applied Economics, 10(2): 257-297. https://doi.org/10.1257/app.20160597

Falk, A. - Becker, A. - Dohmen, T. - Enke, B. - Huffman, D. - Sunde, U. (2018): Global evidence on economic preferences. The Quarterly Journal of Economics, 133(4): 1645-1692. https:// doi.org/10.1093/qje/qjy013

Golsteyn, B.H. - Grönqvist, H. - Lindahl, L. (2014): Adolescent time preferences predict lifetime outcomes. The Economic Journal, 124: 739-761. https://doi.org/10.1111/ ecoj.12095

Gneezy, U. - Potters, J. (1997): An experiment on risk taking and evaluation periods. The Quarterly Journal of Economics, 112(2): 631-645. https://doi. org/10.1162/003355397555217

Gresvik, O. - Haare, H. (2009): Costs in the payment system. Economic Bulletin, 80(1): 16-27. Norges Bank.

Horn, D. - Kiss, H.J. (2019): Time preferences and their life outcome correlates: Evidence from a representative survey. Budapest Working Papers on the Labour Market 1901, Institute of Economics, Centre for Economic and Regional Studies, Hungarian Academy of Sciences. https://doi.org/10.2139/ssrn.3346024

Ilyés, T. - Varga, L. (2015): Show me how you pay and I will tell you who you are - Sociodemographic determinants of payment habits. Financial and Economic Review, 14(2): 25-61. https://en-hitelintezetiszemle.mnb.hu/letoltes/2-ilyes-varga-en.pdf 
Jayaratne, J. - Strahan, P.E. (1996): The finance-growth nexus: Evidence from bank branch deregulation. The Quarterly Journal of Economics, 111(3): 639-670. https://doi. org/10.2307/2946668

Kaboski, J.P. - Townsend, R. M. (2012): The impact of credit on village economies. American Economic Journal: Applied Economics, 4(2): 98-133. https://doi.org/10.1257/app.4.2.98

Karlan, D. - Morduch, J. (2010): Access to Finance. In: Rodrick, D. - Rosenzweig, M.R. (ed.): Handbook of Development Economics, Vol. 5, pp. 4703-4784. https://doi.org/10.1016/ B978-0-444-52944-2.00009-4

Karlan, D. - Osei, R. - Osei-Akoto, I. - Udry, C. (2014): Agricultural decisions after relaxing credit and risk constraints. The Quarterly Journal of Economics, 129(2): 597-652. https:// doi.org/10.1093/qje/qju002

Levine, R. (2005): Finance and growth: theory and evidence. In: Aghion, P. - Durlauf, S.N. (ed.): Handbook of Economic Growth, Vol. 1, pp. 865-934. https://doi.org/10.1016/S15740684(05)01012-9

OECD (2015): National Strategies for Financial Education: OECD/INFE Policy Handbook.

Pitt, M.M. - Khandker, S.R. (1998): The impact of group-based credit programs on poor households in Bangladesh: Does the gender of participants matter? Journal of Political Economy, 106(5): 958-996. https://doi.org/10.1086/250037

Sutter, M. - Kocher, M.G. - Glätzle-Rützler, D. - Trautmann, S.T. (2013): Impatience and uncertainty: Experimental decisions predict adolescents' field behavior. American Economic Review, 103(1): 510-531. https://doi.org/10.1257/aer.103.1.510

Tarozzi, A. - Desai, J. - Johnson, K. (2015): The impacts of microcredit: Evidence from Ethiopia. American Economic Journal: Applied Economics, 7(1): 54-89. https://doi. org/10.1257/app.20130475

Turján, A. - Divéki, É. - Keszy-Harmath, É. - Kóczán, G. - Takács, K. (2011): Nothing is free: A survey of the social cost of the main payment instruments in Hungary. MNB Occasional Papers 93. 